\title{
THE EFFECT OF ATTITUDES, ORGANIZATIONAL COMMITMENTS, SEVERITY OF CHEATING LEVELS, PERSONAL COST OF REPORTING AND JOB COMMITMENT TO WHISTLEBLOWING INTENTIONS
}

\author{
Komarudin Mustopa' ${ }^{1}$ Asep Kurniawan ${ }^{2}$ Trisandi Eka Putri $^{2}$ \\ ${ }^{1}$ STIE Sutaatmadja, Subang, Indonesia \\ komarudinmustopa72@gmail.com
}

INFO ARTIKEL

Histori Artikel :

Tgl. Masuk :

Tgl. Diterima :

Tersedia Online :

Keywords:

Intention to Whistleblowing, Attitude,

Organizational Commitment, Fraud

Severity Level, Personal Cost of

Reporting, Job Commitment
ABSTRAK/ABSTRACT

This study aims to determine the effect of Attitudes, Organizational Commitments, Severity of Cheating Levels, Personal Cost of Reporting and Professional Commitment to whistleblowing intentions. Data collection techniques are questionnaires. The population in this study were all Village government apparatus in Subang Regency and the sample in this study were 200 respondents. Hypothesis testing uses multiple regression analysis.

The results of this study indicate: (1) attitude influences the intention to conduct whistleblowing; (2) organizational commitment does not affect the intention to conduct whistleblowing; (3) Fraud severity level influences the intention to conduct whistleblowing; Personal Cost of Reporting has a negative effect on the intention to do a whistleblowing; (5) Job commitment influences the intention to conduct whistleblowing

\section{PENDAHULUAN}

Tindak kecurangan yang terjadi di Indonesia baik di sektor privat maupun sektor pemerintahan menjadi isu penting yang menyita perhatian masyarakat saat ini. Tindak kecurangan atau yang lebih dikenal dengan fraud menurut Association of certified Fraud Examiner dibagi menjadi 3 tipologi tindakan yaitu: penggelapan asset, pernyataan yang salah dan korupsi. Dari ketiga tindakan tersebut, korupsi merupakan tindakan yang marak terjadi dan merupakan salah satu masalah substantif yang saat ini di hadapi oleh Pemerintahan Indonesia.

\begin{tabular}{lll}
\multicolumn{2}{c}{ Berdasarkan data yang } \\
diterbitkan oleh Transparency \\
International mengenai Corruption
\end{tabular}
Perceptions Index (CPI) tahun 2018, Indonesia menempati peringkat ke-89 dari 180 negara di dunia. Indeks persepsi korupsi dari Transparency International ini menggunakan skala 0100. Pada tahun 2018, dua pertiga lebih dari 180 negara memperoleh nilai CPI di bawah 50. Hal ini menunjukan bahwa adanya kegagalan dari sebagian besar negara untuk mengendalikan korupsi. Indonesia sendiri merupakan negara yang termasuk kedalam dua pertiga negara yang memeperoleh $\mathrm{CPI}$ dibawah 50 
dengan perolehan nilai CPI 38. Maka dari itu, Indonesia dapat dikatakan sebagai negara dengan tingkat korupsi yang terbilang cukup tinggi di dunia.

Tindak pidana korupsi yang terjadi di Indonesia kerap terjadi dan seaakan menjadi budaya yang sulit untuk dibenahi. Misalnya kasus korupsi yang melibatkan anggota DPRD kota Malang yang terjadi di tahun 2018. Kasus tersebut merupakan kasus yang dapat dikatakan miris karena melibatkan sejumlah 41 dari 45 anggota DPRD Malang atau sekitar 91\% dari anggota DPRD Malang dinyatakan terlibat korupsi. Kemudian di awal tahun 2019, masyarakat dibuat terkejut dengan terungkapnya kasus korupsi yang dilakukan oleh Bupati Kotawaringin Timur yang bernama Supian Hadi. Kerugian yang dialami negara atas kasus tersebut sebesar Rp. 5.8 triliun yang bahkan lebih besar nilai kerugiannya dari kasus E-KTP dan BLBI (Sumber: Detik.com). Kasus korupsi memang kerap kali melibatkan pemerintah daerah bahkan menurut Indonesia Corruption Watch, kasus korupsi terbanyak berdasarkan lembaga dipimpin oleh lembaga pemerintahan di tingkat Kabupaten. Akan tetapi, sejak tahun 2015 telah terjadi perluasan tren kecurangan seperti korupsi yang sampai saat ini telah menjalar ke tingkat pemerintahan yang lebih rendah yakni Pemerintahan Desa. Kasus korupsi yang terjadi di Desa menempati urutan kedua setelah tingkat Kabupaten berdasarkan lembaga kasus korupsi terbanyak (Sumber: ICW).

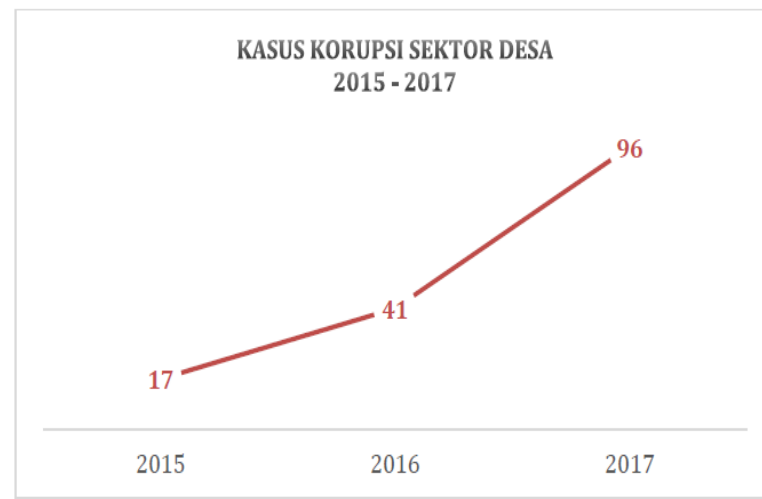

\section{Gambar 1}

Tren Korupsi Sektor Desa

Di tahun 2018, kasus kecurangan di tingkat pemerintahan desa masih kerap terjadi dan cenderung mengalami kenaikan dari tahun sebelumnya. Kasus korupsi pada tahun 2018 pada pemerintahan desa bertambah menjadi 104 kasus dengan ditetapkannya 102 orang kepala desa dan 22 orang aparatur desa. Kasus tersebut diantaranya terjadi di Desa Wanajaya dan Desa Cinangsi yang terletak di Kabupaten Subang.

Salah satu cara yang efektif untuk mendeteksi adanya korupsi adalah dengan adanya whistleblowing. Penelitian ini memiliki tujuan untuk menguji faktor-faktor yang mempengaruhi minat whistle-blowing aparatur pemerintahan Desa di Kabupaten Subang. Adapun factor tersebut terdiri dari sikap, komitmen organisasi, tingkat keseriusan kecurangan, personal cost of reporting, dan komitmen organisasi.

Motivasi dilakukannya penelitian ini adalah pertama, adanya hasil 
penelitian yang berbeda-beda, dimana hal ini menunjukkan adanya kesenjangan penelitian (research gap). Motivasi kedua adalah maraknya kasus korupsi di lingkungan pemerintah desa yang beberapa tahun terakhir mengalami kenaikan yang signifikan sehingga peneliti tertarik ingin mengetahui faktor apa saja yang mempengaruhi fenomena tersebut.

\section{TINJAUAN PUSTAKA}

\section{Theory Planed Behaviour}

Teori perilaku rencanaan (theory of planned behavior/TPB) merupakan pengembangan lebih lanjut dari theory of reasoned action (TRA), yang dikenalkan oleh Fishbein dan Ajzen (1975). Teori of planned behavior menganggap bahwa teori sebelumnya mempunyai keterbatasan, yaitu hanya dimaksudkan untuk menjelaskan perilaku-perilaku yang akan dikerjakan secara sukarela, bukan perilaku-perilaku yang diwajibkan. TPB mengembangkan dan memperkuat TRA dengan menambahkan sebuah variabel yaitu pengendalian perilaku persepsian (perceived behavioral control).

TPB menjelaskan bahwa niat berperilaku (behavioral intention) tidak hanya dipengaruhi oleh sikap terhadap perilaku (attitude towards behavior) dan norma subyektif (subjective norm), tetapi juga dipengaruhi oleh kontrol keperilakuan yang dirasakan (perceived behavioral control). Teori ini didasarkan pada asumsi bahwa manusia adalah makhluk yang rasional yang akan memperhitungkan implikasi dari tindakan mereka sebelum mereka memutuskan untuk melakukan suatu perilaku yang akan mereka lakukan.

\section{Whistleblowing}

$\begin{array}{cr}\text { Menurut Komite } & \text { Nasiona } \\ \text { Kebijakan Governance } & \text { (2008) }\end{array}$ whistleblowing adalah pengungkapan tindakan pelanggaran atau pengungkapan perbuatan yang melawan hukum, perbuatan tidak etis/tidak bermoral atau perbuatan lain yang dapat merugikan organisasi maupun pemangku kepentingan, yang dilakukan oleh karyawan atau pimpinan organisasi kepada pimpinan organisasi atau lembaga lain yang dapat mengambil tindakan atas pelanggaran tersebut. Pengungkapan ini umumnya dilakukan secara rahasia (confidential) dan harus dilakukan dengan iktikad baik dan bukan merupakan suatu keluhan pribadi ataupun didasari kehendak buruk/fitnah.

\section{Sikap}

Menurut Kamus Besar Bahasa Indonesia (KBBI), sikap merupakan suatu perbuatan yang didasarkan atas pendirian dan keyakinan. Sementara menurut Soetarno (1994) menyatakan bahwa sikap merupakan pandangan atau perasaan yang disertai kecenderungan untuk bertindak terhadap obyek tertentu. Sikap senantiasa diarahkan kepada sesuatu artinya tidak ada sikap tanpa obyek. Sikap diarahkan kepada benda-benda, orang, peritiwa, pandangan, lembaga, norma dan lain-lain.

\section{Komitmen Organisasi}

Mowday, dkk (1979) dalam Marliza (2018) mendefinisikan komitmen organisasi sebagai kekuatan relatif identifikasi dan keterlibatan individu dalam organisasi tertentu yang dapat ditandai dengan tiga faktor 
terkait yaitu: pertama, keyakinan yang kuat dan penerimaan terhadap tujuan dan nilai-nilai organisasi. Kedua, kesediaan untuk mengerahkan usaha yang cukup atas nama organisasi. Dan ketiga, keinginan yang kuat untuk mempertahankan keanggotaan dalam organisasi (loyalitas).

\section{Tingkat Keseriusan Kecurangan}

Tingkat keseriusan kecurangan merupakan tingkatan yang menggambarkan seberapa material atau seberapa signifikan akibat yang ditimbulkan dari adanya kecurangan tersebut terhadap organisasi. Tingkat keseriusan kecurangan bisa saja berbeda antara anggota dengan anggota organisasi yang lainnya. Hal tersebut terjadi karena adanya perbedaan persepsi yang berkaitan dengan besar kecilnya nilai dari kecurangan tersebut (Bagustianto, 2014).

\section{Personal Cost of Reporting}

Personal cost of reporting adalah pandangan pegawai terhadap risiko pembalasan/balas dendam atau sanksi dari anggota organisasi, yang dapat mengurangi minat pegawai untuk melaporkan wrongdoing/kecurangan (Schutlz et al., 1993 dalam Bagustianto, 2014). Seorang pegawai yang mengetahui adanya tindk kecurangan bisa saja mengurungkan niatnya untuk melakukan pengungkapan karena adanya ketakutan atas ancaman balas dendam sebagai akibat dari perbuatannya. Maka dari itu, semakin tinggi pandangan seseorang terhadap resiko balas dendam, semakin rendah kemungkinan seseorang tersebut akan mengungkapkan kecurangan yang diketahuinya.

\section{Komitmen Pekerjaan}

Larkin (1990) dalam putra (2018) menyatakan bahwa pada dasarnya komitmen pekerjaan merupakan suatu persepsi dan keyakinan yang berdasarkan pada loyalitas, harapan dan tekad seseorang yang kemudian dituntun oleh sebuah sistem, norma dan nilai yang dapat menuntun dan mengarahkan orang tersebut agar senantiasa untuk selalu bertindak dan berperilaku sesuai dengan aturan dan prosedur tertentu (yang telah diatur dan disusun sebelumnya) dalam upaya dan keinginan untuk menjalankan setiap kewajibannya. Seorang yang berkomitmen pada pekerjaan memercayai dan menerima tujuan pekerjaan serta berkeinginan untuk melakukan berbagai upaya demi mencapai tujuan pekerjaan tanpa diminta (Agustin, 2016).

\section{Kerangka Konseptual dan Hipotesis}

Berdasarkan kajian empiris sebelumnya, penelitian ini kemudian menggunakan theory of planned behavior (TPB) yang dikenalkan oleh Ajzen (1991). Penelitian ini menggunakan niat (intention) untuk melakukan whistleblowing sebagai variabel dependen, sehingga kerangka konseptual disajikan sebagai berikut: 


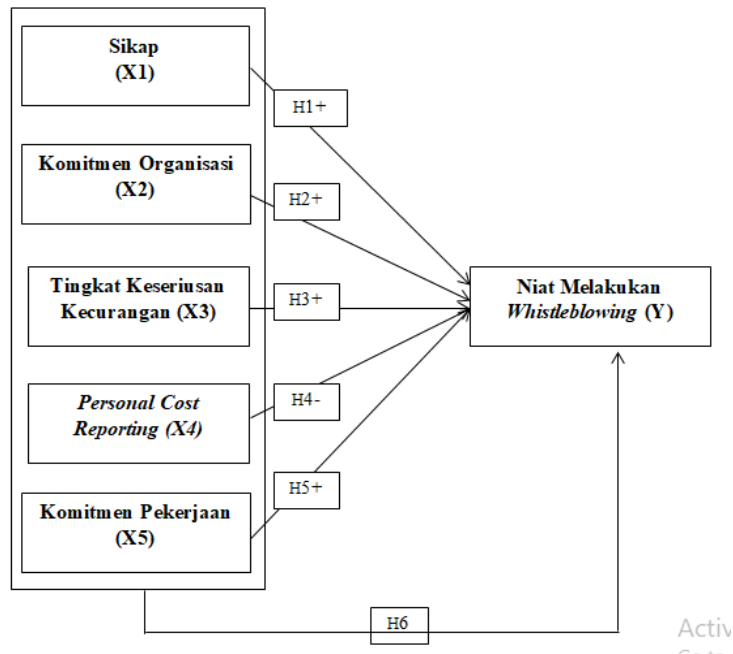

Gambar 2

Kerangka Konseptual

Pengaruh Sikap Terhadap Niat Melakukan Whistleblowing

Menurut Saifudin A. (2005) : "Sikap adalah suatu bentuk evaluasi/reaksi terhadap suatu obyek, memihak/tidak memihak yang merupakan keteraturan tertentu dalam hal perasaan (afeksi), pemikiran (kognisi) dan predisposisi tindakan (konasi) seseorang terhadap suatu aspek di lingkungan sekitarnya." Dengan demikian, sikap seseorang mengenai tindakan whistleblowing akan dipengaruhi oleh pertimbangan mengenai memihak atau tidaknya serta baik dan buruknya tindakan whistleblowing tersebut bagi seseorang.

(2018) dalam penelitiannya menyebutkan bahwa sikap berpengaruh positif terhadap niat untuk melakukan whistleblowing. Semakin tinggi sikap dalam suatu organisasi maka semakin tinggi pula niat pegawai untuk melakukan whistleblowing. Hal tersebut sejalan dengan penelitian yang dilakukan Marantika, Yuniarta dan Anantawikrama (2017) yang menyatakan bahwa sikap berpengaruh positif terhadap niat pegawai negeri untuk melakukan tindakan whistleblowing. Berdasarkan uraian tersebut, maka dirumuskan hipotesis sebagai berikut:

Berdasarkan uraian tersebut, maka dirumuskan hipotesis sebagai berikut:

H1 : Sikap berpengaruh positif terhadap niat melakukan whistleblowing

\section{Pengaruh Komitmen Organisasi Terhadap Niat Melakukan Whistleblowing}

Komitmen organisasi adalah loyalitas karyawan terhadap organisasi melalui pemeliharaan sasaransasaran, nilai-nilai organisasi, kesedihan, atau kemauan untuk berusaha menjadi bagian dari organisasi, serta keinginan untuk bertahan didalam organisasi (Hatmoko, 2006). Pegawai yang memiliki komitmen organisasi yang tinggi didalam dirinya akan timbul rasa memiliki organisasi (sense of belonging) yang tinggi sehingga ia tidak akan merasa merasa ragu untuk melakukan tindakan whistleblowing karena ia yakin tindakan tersebut akan melindungi organisasi dari kehancuran (Marliza, 2018).

Penelitian yang dilakukan Husniati (2017) menyebutkan bahwa komitmen organisasi berpengaruh terhadap Intensi Untuk Melakukan whistleblowing. Hal tersebut sejalan dengan hasil penelitian Janitra (2017) dan Wahyuningsih (2016) yang samasama menyebutkan bahwa komitmen organisasi berpengaruh positif 
terhadap whistleblowing internal. Berdasarkan uraian tersebut, maka dirumuskan hipotesis sebagai berikut:

$\mathrm{H} 2$ : Komitmen organisasi berpengaruh positif terhadap niat melakukan whistleblowing.

\section{Pengaruh Tingkat Keseriusan Kecurangan Terhadap Niat Melakukan Whistleblowing}

Tingkat keseriusan kecurangan merupakan tingkatan yang menggambarkan seberapa material atau seberapa signifikan akibat yang ditimbulkan dari adanya kecurangan tersebut terhadap organisasi. Anggota organisasi yang mengetahui ataupun mengamati adanya tindakan wrongdoing atau kecurangan, terlebih lagi jika tindakan wrongdoing tersebut bersifat serius, maka ia akan lebih cenderung ingin melakukan tindakan whistleblowing (Near dan Miceli, 1985 dalam Putra, 2018). Hal tersebut terjadi karena mereka menyadari bahwa tingkat keseriusan kecurangan yang mereka ketahui bisa saja mengancam keberlangsungan organisasi. Maka dari itu semakin tinggi keseriusan tingkat kecurangan maka akan mendorong seseorang untuk melakukan tindakan whistleblowing.

Penelitian yang dilakukan Aliyah dan Marisan (2017) pada Pegawai Negeri Sipil (PNS) di SKPD Kabupaten Jepara menyebutkan bahwa tingkat keseriusan kecurangan berpengaruh positif dan signifikan terhadap minat pegawai dalam melakukan tindakan whistleblowing. Hal tersebut sejalan dengan hasil penelitian yang dilakukan oleh Wakerkwa, Falah dan Safkaur (2018), Bagustianto dan Nurkholis (2014), Marliza (2018) dan Putra
(2018) yang menyatakan bahwa tingkat keseriusan kecurangan berpengaruh positif dan signifikan terhadap minat melakukan tindakan whistleblowing. Berdasarkan uraian tersebut, maka dirumuskan hipotesis sebagai berikut:

H3 : Tingkat keseriusan kecurangan berpengaruh positif terhadap niat melakukan whistleblowing

\section{Pengaruh Personal Cost of Reporting Terhadap Niat Melakukan Whistleblowing}

Sebelum mengambil suatu tindakan pelaporan, seseorang biasanya akan melakukan pertimbangan-pertimbangan lain terutama yang menyangkut hal pribadinya. Pertimbangan tersebut akan memberikan penilaian terkait efek apa yang akan timbul baik terhadap dirinya maupun orang-orang di lingkungan sekitarnya. Personal cost of reporting adalah pandangan pegawai terhadap risiko pembalasan/balas dendam atau sanksi dari anggota organisasi, yang dapat mengurangi minat pegawai untuk melaporkan wrongdoing (Schutlz et al., 1993). Maka dari itu, semakin tinggi persepsi personal cost of reporting seseorang maka akan semakin berkurang niat dari orang tersebut untuk melakukan tindakan whistleblowing.

Penelitian yang dilakukan Aliyah dan Marisan (2017) pada PNS di 30 SKPD Kabupaten Jepara menyebutkan bahwa personal cost berpengaruh negative dan signifikan terhadap minat pegawai melakukan whistleblowing. Hal tersebut penelitian ini sejalan dengan hasil penelitian yang 
dilakukan oleh Lestari dan Yaya (2017) yang menyebutkan bahwa personal cost berpengaruh negative terhadap niat melaksanakan tindakan whistleblowing oleh aparatur sipil negara. Berdasarkan uraian tersebut, maka dirumuskan hipotesis sebagai berikut:

$\mathrm{H} 4$ : Personal cost of reporting berpengaruh negative terhadap niat melakukan whistleblowing.

\section{Pengaruh Komitmen Pekerjaan Terhadap Niat Melakukan Whistleblowing}

Menurut Utami dan Noegroho (2007) :

Komitmen profesi/pekerjaan ialah sebuah keyakinan seseorang akan penerimaan nilai dan tujuan profesinya, suatu keinginan untuk selalu senantiasa melakukan berbagai upaya dan usaha tertentu yang maksimal untuk dan atas nama profesinya, dan adanya suatu keinginan untuk selalu mempertahankan keanggotaannya pada profesi/pekerjaannya.

Ketika seseorang memiliki komitmen pekerjaan yang tinggi, maka orang tersebut akan cenderung menjaga nama baik profesi/pekerjaan yang diembannya tersebut. Maka ketika ada rekan kerjanya yang melakukan tindak kecurangan yang berpotensi merusak nama baik profesinya, seseorang yang memiliki komitmen profesi/pekerjaan yang tinggi cenderung untuk lebih mau melakukan tindakan whistleblowing.

Dalam penelitian yang dilakukan Nugraha (2017) menyebutkan bahwa komitmen profesi berpengaruh positif terhadap whistleblowing. Hal tersebut sejalan dengan hasil penelitian yang dilakukan Putra (2018) yang menyebutkan bahwa komitmen profesi berpengaruh positif terhadap niat melakukan whistleblowing. Maka berdasarkan uraian tersebut, dirumuskan hipotesis sebagai berikut:

H5 : Komitmen pekerjaan berpengaruh positif terhadap niat melakukan whistleblowing

\section{Pengaruh Sikap, Komitmen Organisasi, Tingkat Keseriusan Kecurangan, Personal Cost of Reporting dan Komitmen Pekerjaan Terhadap Niat Melakukan Whistleblowing}

Berdasarkan teori dan penelitian terdahulu yang telah diuraikan di atas, maka faktor yang dapat berpengaruh terhadap niat seseorang untuk melakukan tindakan whistleblowing yaitu sikap, komitmen organisasi, tingkat keseriusan kecurangan, personal cost of reporting dan komitmen pekerjaan. Setelah dilakukan pengujian secara parsial terhadap kelima faktor tersebut, kemudian dilakukan pengujian secara simultan. Adapun hubungan dari kelima faktor tersebut secara bersamasama yaitu dengan terciptanya pegawai desa yang memiliki sikap yang cenderung berpihak pada whistleblowing, berkomitmen kepada organisasi desa dan berkomitmen kepada pekerjaan yang diembannya 
mampu mendorong pegawai tersebut untuk melakukan tindakan whistleblowing. Diharapkan juga dengan terciptanya pegawai desa yang memiliki perspektif tingkat keseriusan kecurangan dan pandangan yang rendah terhadap personal cost mampu mempengaruhi pegawai yang bersangkutan berminat untuk melakukan tindakan whistleblowing ketika ditemukannya kecurangan. Maka berdasarkan uraian tersebut, dirumuskan hipotesis sebagai berikut : H6 : Sikap, Komitmen organisasi, Tingkat Keseriusan Kecurangan, Personal Cost of Reporting dan Komitmen Pekerjaan secara bersamasama berpengaruh terhadap niat untuk melakukan whistleblowing

\section{METODOLOGI PENELITIAN}

\section{Jenis Penelitian}

Penelitian ini dilakukan dengan menggunakan pendekatan kuantitatif. Adapun metode yang dipilih dan akan digunakan di dalam penelitian ini yaitu dengan menggunakan metode survei. Penelitian survey adalah penelitian yang dilakukan pada populasi besar maupun kecil, tetapi data yang dipelajari adalah data dari sampel yang diambil dari populasi tersebut, sehingga ditemukan kejadian-kejadian relative, distribusi, dan hubunganhubungan antar variabel sosiologis maupun psikologis. (Sugiyono, 2014).

\section{Jenis dan Sumber Data}

Jenis dan sumber data yang digunakan dalam penelitian ini adalah data primer. Data primer adalah data yang mengacu pada informasi yang diperoleh dari tangan pertama oleh peneliti yang berkaitan dengan variabel minat untuk tujuan spesifik studi. Sumber data primer adalah responden individu, kelompok fokus, internet juga dapat menjadi sumber data primer jika koesioner disebarkan melalui internet (Uma Sekaran, 2006).

\section{Populasi dan Sampel}

Menurut Sugiyono (2014:80), populasi adalah wilayah generalis yang terdiri atas: obyek/subyek yang mempunyai kualitas dan karakteristik tertentu yang ditetapkan oleh peneliti untuk dipelajari dan kemudian ditarik kesimpulannya. Jadi populasi bukan sekedar data yang terdapat dari obyek atau subyek tertentu tetapi meliputi karakteristik atau sifat yang terdapat dalam obyek atau subyek tersebut. Populasi di dalam penelitian ini adalah seluruh aparatur perangkat desa di Kabupaten Subang.

Menurut Sugiyono (2014:81), sampel adalah bagian dari jumlah dan karakteristik yang dimiliki oleh populasi tersebut. Bila populasi besar, dan peneliti tidak mungkin mempelajari semua yang ada pada populasi, misalnya karena keterbatasan dana, tenaga dan waktu, maka peneliti dapat menggunakan sampel yang diambil dari populasi itu. Jumlah sampel yang digunakan dalam penelitian ini mengacu pada saran Roscoe (1975) yang dikutip Uma Sekaran (2006) yang memberikan acuan bahwa ukuran sampel kebanyakan penelitian berkisar 
antara 30-500. Sampel dalam penelitian ini sebanyak 200 responden.

\section{Operasional Variabel}

Penelitian ini menggunakan enamt variabel yang terdiri dari lima variabel bebas (independen) dan satu variabel terikat (dependen). Variabel bebas dalam penelitian ini adalah; sikap, komitmen organisasi, tingkat keseriusan kecurangan, personal cost of reporting, dan komitmen pekerjaan. Sedangkan variabel terikatnya adalah niat untuk melakukan whistleblowing.
a. Niat
untuk
Melakukan

\section{Whistleblowing}

Untuk mengukur niat, diajukan tujuh pernyataan yang harus dijawab oleh responden. Pernyataan yang diajukan kepada responden digunakan untuk melihat bagaimana niat responden untuk menjadi whistleblower. Setiap pernyataan kemudian diukur menggunakan skala likert yang terdiri dari lima kriteria yaitu: sangat tidak setuju, tidak setuju, netral, setuju dan sangat Setuju.

b. Sikap

Untuk mengukur sikap, diajukan lima pernyataan yang harus dijawab oleh responden. Pernyataan yang diajukan kepada responden digunakan untuk mengukur perasaan dari seseorang terhadap tindakan whistleblowing. Setiap pernyataan kemudian diukur menggunakan skala likert yang terdiri dari lima kriteria yaitu: sangat tidak setuju, tidak setuju, netral, setuju dan sangat Setuju.

c. Komitmen Organisasi

Untuk mengukur komitmen organisasi, diajukan 6 pernyataan yang harus dijawab oleh responden. Pernyataan yang diajukan kepada responden digunakan untuk menilai seberapa loyal responden terhadap organisasinya. Setiap pernyataan kemudian diukur menggunakan skala likert yang terdiri dari lima kriteria yaitu: sangat tidak setuju, tidak setuju, netral, setuju dan sangat Setuju.

d. Tingkat Keseriusan Kecurangan

Untuk mengukur tingkat keseriusan kecurangan, diajukan 5 pernyataan yang harus dijawab oleh responden. Pernyataan yang diajukan kepada responden digunakan untuk mengetahui niat whistleblowing responden jika dihadapkan dengan besar kecilnya kecurangan. Setiap pernyataan kemudian diukur menggunakan skala likert yang terdiri dari lima kriteria yaitu: sangat tidak setuju, tidak setuju, netral, setuju dan sangat Setuju.

\section{e. Personal Cost of Reporting}

Untuk mengukur komitmen organisasi, diajukan 6 pernyataan yang harus dijawab oleh responden. Pernyataan yang diajukan kepada responden digunakan untuk melihat pandangan responden terhadap resik-o atas pelaporannya. Setiap pernyataan kemudian diukur menggunakan skala likert yang terdiri dari lima kriteria yaitu: sangat tidak setuju, tidak setuju, netral, setuju dan sangat Setuju.

f. Komitmen Pekerjaan

Untuk mengukur komitmen pekerjaan, diajukan 5 pernyataan 
yang harus dijawab oleh responden. Pernyataan yang diajukan kepada responden digunakan untuk menilai seberapa loyal responden terhadap pekerjaannya. Setiap pernyataan kemudian diukur menggunakan skala likert yang terdiri dari lima kriteria yaitu: sangat tidak setuju, tidak setuju, netral, setuju dan sangat Setuju.

\section{Teknik Analisis Data dan Uji Hipotesis}

Untuk menganalisis data dalam penelitian ini digunakan metode analisis deskriptif dan analisis statistik dengan alat bantu SPSS for windows versi 22. Penelitian ini menggunakan analisis regresi linier berganda untuk mengetahui seberapa besar pengaruh variabel sikap, komitmen organisasi, tingkat keseriusan kecurangan, personal cost of reporting, dan komitmen pekerjaan terhadap niat untuk melakukan tindakan whistleblowing. Dari nilai koefisien dapat diketahui pengaruh/kontribusi masing-masing variabel yang ada. Adapun rumus persamaan regresinya adalah:

$$
Y i=a+\beta_{1} X_{1}+\beta_{2} X_{2}+\beta X_{3} X_{3}+\beta{ }_{5+} X_{4}+\beta
$$

Dimana:

$\mathrm{Yi}=$ Niat Melakukan Whistleblowing

$\mathrm{a}=$ Bilangan Konstantan

$\beta=$ Koefisien Arah Regresi

$\mathrm{X}_{1}=$ Sikap

$\mathrm{X}_{2}=$ Komitmen organisasi

$\mathrm{X}_{3}=$ Tingkat Keseriusan Kecurangan

$\mathrm{X}_{4}=$ Personal Cost of Reporting

$\mathrm{X}_{5}=$ Komitmen Pekerjaan

\section{Uji Signifikan Pengaruh Parsial (Uji}

t)

Uji t digunakan untuk menguji signifikansi hubungan antara variabel $X$ dan $Y$ pada taraf signifikansi $\alpha=5 \%$. Hipotesis yang dirumuskan adalah sebagai berikut :

H1: Sikap berpengaruh positif terhadap niat melakukan whistleblowing

H2: Komitmen organisasi berpengaruh positif terhadap niat melakukan whistleblowing

H3: Tingkat keseriusan kecurangan berpengaruh positif terhadap niat melakukan whistleblowing

$\mathrm{H} 4$ : Personal cost of reporting berpengaruh negatif terhadap niat melakukan whistleblowing

H5: Komitmen pekerjaan berpengaruh positif terhadap niat melakukan tindakan whistleblowing

Kriteria Hasil pengujian :

$\mathrm{H}$ ditolak jika signifikansi $\alpha>0,05$

$\mathrm{H}$ diterima jika signifikansi $\alpha<0,05$

\section{Uji Signifikansi Simultan (Uji F)}

Uji F digunakan untuk mengetahui tingkat siginifikansi pengaruh variabelvariabel independen secara bersamasama (simultan) terhadap variabel dependen (Ghozali, 2006). Dalam penelitian ini, hipotesis yang digunakan adalah:

H6 : Sikap, komitmen organisasi, tingkat keseriusan kecurangan, personal cost, dan komitmen pekerjaan secara simultan berpengaruh terhadap niat melakukan whistleblowing

Kriteria Hasil pengujian :

$\mathrm{H}$ ditolak jika signifikansi $\alpha>0,05$

$\mathrm{H}$ diterima jika signifikansi $\alpha<0,05$ 
HASIL PENELITIAN \&

PEMBAHASAN

Hasil Uji Regresi Berganda

Tabel 1: Hasil Uji Analisis Regresi

Berganda

\begin{tabular}{|c|c|c|c|c|c|c|}
\hline \multirow{2}{*}{\multicolumn{2}{|c|}{ Model }} & \multicolumn{2}{|c|}{$\begin{array}{l}\text { Unstandardized } \\
\text { Coefficients }\end{array}$} & \multirow{2}{*}{$\begin{array}{c}\text { Standardized } \\
\text { Coefficients }\end{array}$} & \multirow[b]{2}{*}{$\mathrm{t}$} & \multirow[b]{2}{*}{ Sig. } \\
\hline & & B & Std. Error & & & \\
\hline \multirow[t]{6}{*}{1} & (Constant) & 6.375 & 2.270 & & 2.809 & .005 \\
\hline & $\mathrm{X} 1$ & .207 & .087 & .131 & 2.367 & .019 \\
\hline & $\mathrm{X} 2$ & -.007 & .083 & -.006 & -.090 & .928 \\
\hline & $\mathrm{X} 3$ & .684 & .075 & .547 & 9.091 & .000 \\
\hline & $\mathrm{X} 4$ & -.108 & .044 & -.130 & -2.435 & .016 \\
\hline & $\mathrm{X} 5$ & .285 & .082 & .209 & 3.464 & .001 \\
\hline
\end{tabular}

Berdasarkan tabel 1 diperoleh

koefisien untuk variabel bebas yaitu $X 1=0,207 ; X 2=-0,007 ; X 3=0,684 ; X 4=$ $-0,108 ; X 5=0,285$, dengan konstanta sebesar 6,735. Dengan demikian, dapat dihasilkan persamaan regresi berganda, sebagai berikut:

$\mathrm{Y}=6,735+0,207 \mathrm{X} 1-0,007 \mathrm{X} 2+0,684 \mathrm{X} 3-$ $0,108 \times 4+0,285+e$

Persamaan regresi berganda di atas, memiliki makna sebagai berikut:

1. Konstanta (a) sebesar 6,375; artinya apabila sikap, komitmen organisasi, tingkat keseriusan kecurangan, personal cost of reporting, dan komitmen pekerjaan nilainya 0 , maka niat melakukan tindakan whistleblowing nilainya sebesar 6,375 .

2. Koefisien regresi variabel sikap (X1) menunjukan nilai sebesar 0,207 ; artinya jika sikap mengalami peningkatan satu satuan, maka niat untuk melakukan tindakan whistleblowing akan mengalami peningkatan sebesar 0,207 dengan asumsi variabel independen lainnya bernilai tetap (konstan).
3. Koefisien regresi variabel komitmen organisasi (X2) menunjukan nilai sebesar 0,007 artinya jika komitmen organisasi mengalami peningkatan satu satuan, maka niat untuk melakukan tindakan whistleblowing akan mengalami penurunan sebesar 0,007 dengan asumsi variabel independen lainnya bernilai tetap (konstan).

4. Koefisien regresi variabel tingkat keseriusan kecurangan (X3) menunjukan nilai sebesar 0,684 artinya jika tingkat keseriusan kecurangan mengalami peningkatan satu satuan, maka niat untuk melakukan tindakan whistleblowing akan mengalami peningkatan sebesar 0,684 dengan asumsi variabel independen lainnya bernilai tetap (konstan).

5. Koefisien regresi variabel personal cost of reporting (X4) menunjukan nilai sebesar 0,108 artinya jika personal cost of reporting mengalami peningkatan satu satuan, maka niat untuk melakukan tindakan whistleblowing akan mengalami penurunan sebesar 0,108 dengan asumsi variabel independen lainnya bernilai tetap (konstan).

6. Koefisien regresi variabel komitmen profes (X5) menunjukan nilai sebesar 0,285 artinya jika komitmen pekerjaan mengalami peningkatan satu satuan, maka niat untuk melakukan tindakan whistleblowing akan mengalami peningkatan sebesar 0,285 dengan asumsi variabel independen lainnya bernilai tetap (konstan). 
Hasil Uji Hipotesis

Tabel 2: Hasil Uji Parsial (t)

\begin{tabular}{|c|c|c|c|c|c|c|}
\hline \multirow{2}{*}{\multicolumn{2}{|c|}{ Model }} & \multicolumn{2}{|c|}{$\begin{array}{c}\text { Unstandardized } \\
\text { Coefficients }\end{array}$} & \multirow{2}{*}{\begin{tabular}{|c|}
$\begin{array}{c}\text { Standardized } \\
\text { Coefficients }\end{array}$ \\
Beta \\
\end{tabular}} & \multirow[b]{2}{*}{$\mathrm{t}$} & \multirow[b]{2}{*}{ Sig. } \\
\hline & & $\mathrm{B}$ & Std. Error & & & \\
\hline \multirow[t]{6}{*}{1} & (Constant) & 6.375 & 2.270 & & 2.809 & .005 \\
\hline & $\mathrm{X} 1$ & .207 & .087 & .131 & 2.367 & .019 \\
\hline & $\mathrm{X} 2$ & -.007 & .083 & -.006 & -.090 & .928 \\
\hline & $\mathrm{X} 3$ & .684 & .075 & .547 & 9.091 & .000 \\
\hline & $\mathrm{X} 4$ & -.108 & .044 & -.130 & -2.435 & .016 \\
\hline & $\mathrm{X} 5$ & .285 & .082 & .209 & 3.464 & .001 \\
\hline
\end{tabular}

\section{Pengaruh Sikap (X1) terhadap Niat}

(Y) Berdasarkan pengujian secara parsial pada variabel sikap terhadap niat melakukan tindakan whistleblowing diperoleh nilai koefisien positif sebesar $\beta 1=0,027$ dengan nilai signifikasi sebesar 0,019. Karena nilai signifikan (sig. value) 0,019 lebih kecil daripada 0,05 (sig. tolerance) maka dapat disimpulkan bahwa terdapat pengaruh positif signifikan antara sikap terhadap niat melakukan whistleblowing sehingga $\mathrm{H} 1$ yang menyatakan sikap berpengaruh positif terhadap niat melakukan whistleblowing diterima.

Jika dihubungkan dengan definisi yang dikemukakan oleh Soetarno maka obyek tertentu dalam konteks penelitian ini adalah pelaporan kecurangan (Whistleblowing). Maka dari itu hasil penelitian ini menegaskan bahwa dengan semakin tingginya sikap seseorang yang menunjukan kecenderungan terkait pelaporan kecurangan atau keberpihakannya pada pelaporan kecurangan maka semakin tinggi juga seseorang tersebut untuk berniat melaporkan kecurangan di tempat ia bekerja, khususnya di pemerintahan desa. Dalam hal ini, dapat dikatakan bahwa aparatur pemerintahan tingkat desa di Kabupaten Subang menganggap bahwa whistleblowing merupakan tindakan yang penting, bermanfaat dan merupakan kewajiban yang memang seharusnya dilakukan oleh mereka sebagai pelayan public.

Hasil penelitian ini sejalan dengan penelitian yang pernah dilakukan oleh Wakerwa, Rodika dkk (2018), Marantika, Vina (2017) dan Bagustianto dan Nurkholis. (2014) yang menyebutkan bahwa terdapat pengaruh signifikan positif dari variabel sikap terhadap niat melakukan tindakan whistleblowing.

\section{Pengaruh Komitmen Organisasi (X2) terhadap Niat (Y)}

Berdasarkan pengujian secara parsial pada variabel komitmen organisasi terhadap niat melakukan tindakan whistleblowing diperoleh nilai koefisien negatif sebesar $\beta 2=-0,027$ dengan nilai signifikasi sebesar 0,928. Karena nilai signifikan (sig. value) 0,928 lebih besar daripada 0,05 (sig. tolerance) maka dapat disimpulkan bahwa tidak terdapat pengaruh signifikan antara komitmen organisasi terhadap niat melakukan whistleblowing sehingga $\mathrm{H} 2$ yang menyatakan komitmen organisasi berpengaruh positif terhadap niat melakukan whistleblowing ditolak.

Komitmen organisasi sendiri dapat diartikan sebagai bentuk loyalitas karyawan atau pegawai terhadap organisasi tempat ia bekerja. Menurut Marliza (2018) pegawai yang memiliki komitmen organisasi yang tinggi akan timbul rasa memiliki terhadap organisasi tersebut sehingga ia tidak akan merasa merasa ragu untuk melakukan tindakan whistleblowing karena ia yakin tindakan tersebut akan melindungi organisasi dari kehancuran. Jika dicermati, kehancuran yang dimaksud Marliza dapat diartikan sebagai kemunduran suatu organisasi tersebut sehingga pada akhirnya organisasi tersebut tidak dapat beroperasi seperti 
sedia kala dengan kata lain bangkrut. Ketika suatu organisasi bangkrut tentu akan berdampak pula pada pegawainya karena organisasi itulah mereka bekerja dan mendapatkan penghasilan. Akan tetapi, dalam konteks organisasi desa dapat dikatakan bahwa organisasi desa nerupakan organisasi yang sedikit kemungkinan mengalami adanya kehancuran/kebangkrutan. Hal ini dikarenakan jika dilihat dari segi finansial, Desa merupakan organisasi yang memiliki supply setiap tahunnya dari pemerintah, baik tingkat Kabupaten, tingkat Provinsi, sampai dari tingkat Pusat. Maka dari itu, selama desa dan masyarakatnya masih ada sangat kecil kemungkinannya untuk mengalami kehancuran/kebangkrutan.

Variabel komitmen organisasi tidak berpengaruh terhadap niat melakukan whistleblowing kemungkinan karena adanya anggapan seperti yang dijelaskan diatas, dimana mereka menilai bahwa organisasi desa tidak akan pernah bangkrut sehingga mereka beranggapan tidak mengapa meskipun tidak melaporkan tindak kecurangan. Selain itu, kemungkinan lainnya adalah adanya ketidakpercayaan terhadap organisasi yang menaunginya. Hal tersebut bisa saja terjadi karena adanya anggapan bahwa laporan yang mereka buat tidak akan diproses oleh organisasi dan malah akan menimbukan masalah bagi dirinya sendiri. Belum lagi, penegakan perlindungan hukum terhadap whistleblower masih kurang dilaksanakan dengan baik di Indonesia.

Hasil penelitian ini sejalan dengan hasil penelitisan yang pernah dilakukan oleh Kreshatuti (2014), Putra (2018), dan Aliyah dan Marisan (2017) yang menyatakan bahwa komitmen organisasi tidak berpengaruh signifikan terhadap niat untuk melakukan tindakan whistleblowing.

\section{Pengaruh Tingkat Keseriusan Kecurangan (X3) terhadap Niat (Y)}

Berdasarkan pengujian secara parsial pada variabel tingkat keseriusan kecurangan terhadap niat melakukan tindakan whistleblowing diperoleh nilai koefisien positif sebesar $\beta 3=0,684$ dengan nilai signifikasi sebesar 0,000. Karena nilai signifikan (sig. value) 0,000 lebih kecil daripada 0,05 (sig. tolerance) maka dapat disimpulkan bahwa terdapat pengaruh positif signifikan antara tingkst keseriusan kecurangan terhadap niat melakukan whistleblowing sehingga H3 yang menyatakan tingkat keseriusan kecurangan berpengaruh positif terhadap niat melakukan whistleblowing diterima.

Tingkat keseriusan kecurangan dapat diartikan sebagai tingkatan yang menggambarkan seberapa signifikan akibat yang ditimbulkan dari adanya kecurangan. Keseriusan kecurangan pada tingkat pemerintahan desa dapat berhubungan dengan anggaran desa yang tentu pada akhirnya akan merugikan organisasi desa maupun masyarakat desa. Berdasarkan hasil statistik diatas, ketika terjadi kecurangan yang sifatnya serius maka akan ada dorongan pada aparatur Desa untuk berniat melakukan Whistleblowing. Hal tersebut dapat terjadi karena adanya kesadaran dari aparatur desa bahwasannya kecurangan yang dilakukan dapat merampas hak-hak yang seharusnya dirasakan oleh masyarakat khususnya masyarakt desa. Sehingga hasil pada penelitian ini menegaskan bahwa semakin tinggi keseriusan kecurangan maka akan membuat pegawai semakin memiliki niat untuk melakukan tindakan whistleblowing. 
Hasil tersebut sejalan dengan hasil penelitian yang dilakukan oleh Bagustianto dan Nurkholis (2014), Marliza (2018), Putra (2018), Aliyah dan Marisan (2017), dan Wakerwa, Rodika dkk (2018) yang menyatakan bahwa tingkat keseriusan kecurangan berpengaruh signifikan positif terhadap niat untuk melakukan tindakan whistleblowing.

\section{Pengaruh Personal Cost of Reporting (X4) terhadap Niat (Y)}

Berdasarkan pengujian secara parsial pada variabel personal cost of reporting terhadap niat melakukan tindakan whistleblowing diperoleh nilai koefisien negatif sebesar $\beta 4=0,108$ dengan nilai signifikasi sebesar 0,016. Karena nilai signifikan (sig. value) 0,016 lebih kecil daripada 0,05 (sig. tolerance) dan nilai $\beta 4=0,108$ maka dapat disimpulkan bahwa terdapat pengaruh negatif signifikan antara personal cost of reporting terhadap niat melakukan whistleblowing sehingga $\mathrm{H} 4$ yang menyatakan personal cost of reporting berpengaruh negatif terhadap niat melakukan whistleblowing diterima.

Personal cost of reporting dapat diartikan sebagai pandangan seseorang terhadap adanya balas dendam baik berupa ancaman, pemecatan dan hal lain yang merugikan sebagai konsekuensi atas tindakan pelaporannya. Seringkali seseorang merasa ragu untuk melaporkan kecurangan karena ada kekhawatiran dari dalam dirinya atas apa yang akan ia dapat di kemudian hari dari tindakannya tersebut. Kekhawatiran tersebut semakin menjadi, ketika banyak kasus dimana pihak pelapor justru di cap sebagai orang yang bersalah. Selain itu, ada pula yang diberhentikan dari pekerjaannya dan bahkan adapula yang harus dipenjara sebagai konsekuensi atas pelaporan kecurangan yang ia lakukan. Hal tersebut terjadi karena masih lemahnya penegakan hukum yang ada di Indonesia. Maka dari itu, hasil penelitian ini menegaskan bahwa semakin tinggi pandangan seseorang terhadap personal cost of reporting maka semakin menurun niat untuk melakukan whistleblowing.

Hasil penelitian ini sejalan dengan penelitian yang dilakukan oleh Aliyah dan Marisan pada tahun 2017 dan Wakerwa, Rodika dkk pada tahun 2018 yang menyebutkan bahwa personal cost of reporting berpengaruh signifikan negative terhadap niat untuk melakukan tindakan whistleblowing.

\section{Pengaruh Komitmen Pekerjaan (X3) terhadap Niat (Y)}

Berdasarkan pengujian secara parsial pada variabel komitmen pekerjaan terhadap niat melakukan tindakan whistleblowing diperoleh nilai koefisien positif sebesar $\beta 5=0,285$ dengan nilai signifikasi sebesar 0,001. Karena nilai signifikan (sig. value) 0,001 lebih kecil daripada 0,05 (sig. tolerance) maka dapat disimpulkan bahwa terdapat pengaruh positif signifikan antara komitmen pekerjaan terhadap niat melakukan whistleblowing sehingga $\mathrm{H} 5$ yang menyatakan komitmen pekerjaan berpengaruh positif terhadap niat melakukan whistleblowing diterima.

Komitmen pekerjaan diartikan sebagai kecintaan atau loyalitas seorang pegawai terhadap pekerjaan yang dimilikinya. Hasil penelitian ini menegaskan bahwa semakin tinggi komitmen seseorang terhadap pekerjaannya maka semakin tinggi pula niatan seseorang tersebut untuk melaporkan kecurangan. Hal ini dilakukan demi menjaga nama baik pekerjaan yang diembannya, sehingga apabila ada rekan kerja yang sama 
pekerjaannya melakukan kecurangan maka seseorang yang memiliki komitmen pekerjaan yang tinggi akan cenderung berniat untuk melaporkan kecurangan tersebut. Perlu diketahui, pekerjaan yang dimaksud dalam penelitian ini adalah pekerjaan pegawai desa.

Hasil ini sejalan dengan penelitian terdahulu yang dilakukan Putra (2018) yang menyatakan bahwa terdapat pengaruh signifikan positif anatara variabel komitmen pekerjaan terhadap minat untuk melakukan tindakan whistleblowing.

Hasil Uji Simultan (F) Tabel 3: Hasil Uji Simultan

\begin{tabular}{|c|c|c|c|c|c|c|}
\hline \multicolumn{7}{|c|}{ ANOVA $^{a}$} \\
\hline \multicolumn{2}{|c|}{ Model } & $\begin{array}{l}\text { Sum of } \\
\text { Squares }\end{array}$ & df & Mean Square & $\mathrm{F}$ & Sig. \\
\hline \multirow[t]{3}{*}{1} & Regression & 1209.752 & 5 & \multirow{3}{*}{$\begin{array}{r}241.950 \\
6.946\end{array}$} & \multirow[t]{3}{*}{34.835} & \multirow[t]{3}{*}{$.000^{b}$} \\
\hline & Residual & 1347.443 & 194 & & & \\
\hline & Total & 2557.195 & 199 & & & \\
\hline \multicolumn{7}{|c|}{ a. Dependent Variable: Y } \\
\hline \multicolumn{7}{|c|}{ b. Predictors: (Constant), $x 1, x 2, x 3, x 4, x 5$} \\
\hline
\end{tabular}

Berdasarkan pengujian secara simultan mengenai variabel sikap, komitmen organisasi, tingkat keseriusan kecurangan, personal cost of reporting dan komitmen pekerjaan terhadap niat melakukan tindakan whistleblowing menunjukann $F_{\text {hitung }}$ sebesar 34,835 dengan signifikasi 0,000 . Karena nilai $F_{\text {hitung }} 34,835$ lebih besar dari $F_{\text {tabel }} 2,26$ dan signifikasi 0,000 lebih kecil dari 0,005. Maka dari itu, atas dasar hasil yang ditunjukan dapat disimpulkan bahwa sikap, komitmen organisasi, tingkat keseriusan kecurangan, personal cost of reporting, dan komitmen pekerjaan secara bersama-sama berpengaruh terhadap niat melakukan tindakan whistleblowing. 10.35310/accruals.v4i01.408

\section{KESIMPULAN}

Berdasarkan hasil penelitian di atas, maka diperoleh beberapa kesimpulan sebagai berikut :

1. Hasil penelitian membuktikan bahwa sikap berpengaruh positif signifikan terhadap niat melakukan whistleblowing.

semakin tindakan keberpihakan seseorang mengenai whistleblowing maka semakin tinggi pula seseorang tersebut berniat melakukan whistleblowing.

2. Hasil penelitian membuktikan bahwa komitmen organisasi tidak berpengaruh signifikan terhadap niat melakukan tindakan whistleblowing. Artinya tinggi rendahnya komitmen organisasi seseorang tidak menjadi factor yang mempengaruhi seseorang melakukan whistleblowing.

3. Hasil penelitian membuktikan bahwa tingkat keseriusan kecurangan berpengaruh positif signifikan terhadap niat melakukan tindakan whistleblowing. Artinya, semakin besar keseriusan kecurangan maka semakin tinggi pula seseorang tersebut berniat melakukan whistleblowing

4. Hasil penelitian membuktikan bahwa personal cost of reporting berpengaruh negatif signifikan terhadap niat melakukan tindakan whistleblowing. Artinya, semakin tinggi seseorang memandang resiko pelaporan maka semakin menurun niat seseorang tersebut untuk melakukan whistleblowing. 
5. Hasil penelitian membuktikan bahwa komitmen pekerjaan berpengaruh positif signifikan terhadap niat melakukan tindakan whistleblowing. Artinya, semakin tinggi komitmen seseorang terhadap pekerjaannya semakin tinggi pula orang tersebut memiliki niat melakukan whistleblowing.

6. Hasil pengujian secara simultan menunjukkan secara statistik terbukti bahwa faktor sikap, komitmen organisasi, tingkat keseriusan kecurangan, personal cost of reporting dan komitmen pekerjaan secara bersama-sama (simultan) berpengaruh positif signifikan terhadap niat melakukan tindakan whistleblowing di pemerintahan tingkat Desa di Kabupaten Subang.

\section{IMPLIKASI \& KETERBATASAN}

\section{Saran}

Berdasarkan penelitian yang telah dilakukan, peneliti bermaksud menyampaikan beberapa saran untuk penelitian selanjutnya serta untuk beberapa pihak yang terkait dalam penelitian dengan mengajukan saran sebagai berikut:

1. Bagi Peneliti Selanjutnya

a. Penyebaran kuesioner lebih baik tidak dilakukan pada waktu yang cukup sibuk bagi responden. Hal ini dilakukan supaya pengisian kuesioner dilakukan dengan benar dan tidak asal.

b. Peneliti kedepannya yang ingin melakukan penelitian serupa, akan lebih baik untuk meneliti variabel lainnya yang dapat mempengaruhi niat seseorang untuk melakukan tindakan whistleblowing. Adapun variabel yang bisa

\section{ditambahkan dalam penelitian salah satunya adalah whistleblower protection.}

2. Bagi Desa

Perlu adanya penerapan system pengaduan masyarakat guna wadah keluhan yang dirasakan masyarakat termasuk pelaporan kecurangan seperti pungutan liar dengan menyediakan kotak aduan atau system pengaduan yang berbasis digital dengan merahasiakan identitas pelapor. Hal ini dimaksudkan untuk menekan tindak kecurangan yang sudah dianggap rasional seperti pungutan liar pada masyarakat yang membuat surat keterangan, surat pengantar, surat rekomendasi dan lainnya yang seharusnya tidak dipungut biaya.

\section{Keterbatasan Penelitian}

1. Penelitian ini hanya menggunakan instrumen kuesioner sehingga belum menggambarkan secara utuh kondisi yang terjadi pada objek penelitian.

2. Sampel yang digunakan masih belum proporsional antara jumlah aparatur desa yang satu dengan desa yang lainnya.

Faktor yang diangkat dalam penelitian ini hanya mampu menjelaskan 45,9\% variabel niat melakukan whistleblowing sementara sisanya dijelaskan faktor-faktor lain diluar model penelitian.

\section{REFERENCES}

Ajzen, I. (1991). The theory of planned behavior. Organizational Behavior and Human Decision Processes. https://doi.org/10.1016/07495978(91)90020-T 
Agustin. 2016. Analisis Pengaruh Komitmen Pekerjaanonal, komitmen Organsasi, dan Demografi Terhadap Intensi Melakukan Whistleblowing. Skripsi. Jakarta: Jurusan Akuntansi, Fakultas Ekonomi \& Bisnis. http://repository.uinjkt.ac.id/dspace/bi tstream/123456789/35650/1/CINDY \%20REYNA\%20AGUSTIN-FEB.pdf

Aliyah, Marisan. 2017. Analisis Faktorfaktor Yang Mempengaruhi Pegawai Melakukan Tindakan WhistleBlowing Dengan Reward model sebagai Variabel Moderating. Jurnal Dinamika Ekonomi \& Bisnis. Vol.14, No.1.UNINSU Jepara.

Bagustianto dan Nurkholis. 2014. FaktorFaktor Yang Mempengaruhi Minat Pegawai Negeri Sipil (PNS) Untuk Melakukan Tindakan Whistleblowing (Studi Pada PNS BPK RI). Jurnal Simposium Nasional Akuntansi XVIII.

Bouville, M. (2008). Whistle-blowing and morality. Journal of Business Ethics, 81(3),579-585.

https://doi.org/10.1007/s10551-0079529-7

Badan Pusat Statistik (BPS) Kabupaten Subang. 2015. Jumlah Perangkat Desa/Kelurahan

Chen, C. P., \& Lai, C. T. (2014). To blow or not to blow the whistle: The effects of potential harm, social pressure and organisational commitment on whistleblowing intention and behaviour. Business Ethics, 23(3), 327-342.

https://doi.org/10.1111/beer.12053

Detik. 2019. Kerugian Negara Kasus Bupati KOTIM 5.8 T, KPK: Setara dengan BLBI. (online). (https://news.detik.com/berita/44108 55/kerugian-negara-kasus-bupatikotim-rp-58-t-kpk-setara-dengan-

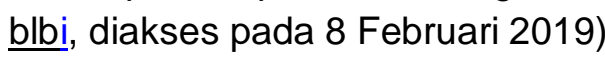

Ghozali. Imam. (2011). Aplikasi Analisis Multivariate dengan Program SPSS.Semarang : Badan Penerbit Universitas Diponegoro.

Handika, M. F. D., \& Sudaryanti, D. (2017). Analisis Faktor-Faktor yang Mempengaruhi Niat Mahasiswa Melakukan Tindakan Whistle-Blowing (Studi Pada Mahasiswa Akuntansi STIE Akuntansi Asia Malang). Jurnal IImiah Bisnis Dan Ekonomi SITE ASIA, 11(1), 56-63.

Husniati, H. S., Wiguna, H., \& Meilda. (2008). Faktor-Faktor Yang Mempengaruhi Intensi Untuk Melakukan Whistleblowing Internal (Studi Empiris Pada Satuan Kerja Perangkat Daerah Kabupaten Rokan Hulu). JOM Fekon, 4.

Indonesia Corruption Watch. (2018). Lonjakan Korupsi di Desa. (Online), (https://antikorupsi.org/id/news/outlo ok-dana-desa2018potensipenyalahgunaananggaran-desa-di-tahun-politik, diakses 28 Desember 2018).

Indonesia Corruption Watch. (2018). Outlook dana desa 2018: Potensi penyalahgunaan anggaran dana desa di tahun politik. (Online), (https://antikorupsi.org/id/news/outlo ok-dana-desa-2018-potensipenyalahgunaan-anggaran-desa-ditahun-politik, diakses 28 Desember 2018).

Janitra. 2017. Pengaruh Etika, Komitmen Pekerjaanonal, Komitmen Organisasi, dan Sensitivitas Etis Terhadap Interna Whistleblowing (Studi Empiris Pada SKPD Kota 
Pekanbaru). JOM Fekon. Vol.4, No.1.Universitas Riau

Komite Nasional Kebijakan Governance. 2008. Pedoman Sistem Pelaporan Pelanggaran-SPP (Whistleblowing System-WBS).

Kompas. 2012. KPK Tetapkan Wali Kota Semarang sebagai Tersangka. (Online), (https://regional.kompas.com/read/2 012/03/16/18293634/KPK.Tetapkan. Walikota.Semarang.sebagai.Tersang ka, diakses 28 Desember 2018)

KotaSubang. 2018. Duh! 2 Kades Di Subang Ditetapkan Jadi Tersangka Korupsi Dana Desa. (Online), (https://www.kotasubang.com/13889/ duh-2-kades-di-subang-ditetapkanjadi-tersangka-korupsi-danadesa/amp?fbclid=IwAR0aJ7TvEMBO VotrR_upVouWRTh1y9IPuvyVRywg Pa3G9nbFSONK9-ITV5Y, diakses pada 7 februari 2019)

Lestari, R., \& Yaya, R. (2017). Whistleblowing Dan Faktor-Faktor Yang Mempengaruhi Niat Melaksanakannya Oleh Aparatur Sipil Negara. Jurnal Akuntansi, 21(3), 336.

https://doi.org/10.24912/ja.v21i3.265

Marliza. 2018. Pengaruh Personal Cost of reporting, Komitmen Organisasi, dan Tingkat Keseriusan Kecurangan Terhadap Niat Melakukan Tindakan Whistleblowing (Studi Empiris pada Organisasi Perangkat Daerah Kota Payakumbuh). Jurnal Akuntansi. Vol.6, No.1. UNP Air tawar Padang

Mesmer-Magnus, J. R., \& Viswesvaran, C. (2005). Whistleblowing in organizations: An examination of correlates of whistleblowing intentions, actions, and retaliation. Journal of Business Ethics, 62(3),
277-297.

https://doi.org/10.1007/s10551-0050849-1

Olken, B. A., \& Pande, R. (2012). Corruption in Developing Countries. Ssrn.

https://doi.org/10.1146/annureveconomics-080511-110917

Putra. 2018. Pengaruh Komitmen Organisasi, Tingkat Keseriusan Kecurangan, Komitmen Pekerjaan, dan Intesitas Moral Terhadap Niat Melakukan Whistleblowing. Skripsi. Yogyakarta: Jurusan Akuntansi, Fakultas Ekonomi universitas Islam Indonesia.

Porter, L. W., Mowday, R. T., \& Steers, R. M. (1979). The measurement of organizational commitment. Journal of Vocational Behavior, 14(2), 224247. https://doi.org/10.1016/0001$8791(79) 90072-1$

Ramadhany. 2017. Personal Cost dan Efektivitas Whistleblowing System Terhadap Pendeteksian Fraud Dengan Self Efficacy Sebagai Pemoderasi (Studi pada KPP Pratama Makasar Selatan. Skripsi. Makasar: Jurusan Akuntansi, Fakultas Ekonomi\& Bisinis Islam. repositori.uinalauddin.ac.id/8061/1/St. \%20Nur\%20Faika\%20Ramadhany.p $d f$

Rappler. 2015. Setya Novanto Laporkan Menteri ESDM Sudirman Said ke Mabes Polri. (Online),(https://www.rappler.com/ind onesia/115441-setya-novantolaporkan-sudirman-said-ke-polisi, diakses 29 Desember 2018)

Schultz, J. J., Johnson, D. A., Morris, D., \& Dyrnes, S. (1993). An Investigation of 
the Reporting of Questionable Acts in an International Setting. Journal of Accounting Research. https://doi.org/10.2307/2491165

Sugiyono. 2014. Metode Penelitian Kuantitatif, Kualitatif dan $R \& D$. Cetakan ke-21 Desember 2014. Bandung: CV Alfabeta.

Transparency International. 2019. Corruption Perceptions Index 2018. (Online), (https://www.transparency.org/cpi20 18, diakses 7 Februari 2019)

Utami, I., \& Noegroho, yesta A. K. (2007). Pengaruh Locus of Control, Komitmen Pekerjaan, Pengalaman Audit terhadap Perilaku Akuntan Publik dalam Konflik Audit dengan Kesadaran Etis sebagai Variabel Pemoderasi. Jurnal Akuntansi dan Keuangan Indonesia2, 4(2), 193210.

Undang-Undang Nomor 06 Tahun 2014 tentang Desa.

Undang-undang Republik Indonesia Nomor 31 Tahun 1999 Tentang
Pemberantasan Tindak Pidana Korupsi

Vices, P., Benefits, P., Mandeville, B., Leff, N., Development, E., Bureaucratic, T., $\quad \ldots \quad$ Simpkins, E. (n.d.). CORRUPTION AND POLITICAL DEVELOPMENT : A COST-BENEFIT ANALYSIS *, 417-427.

Wakerwa, Rodika dkk. 2018. Faktor-faktor yang Mempengaruhi Aparatur Sipil Negara (ASN) Untuk Melakukan Tindakan Whistleblowing Pada PEMDA Provinsi Papua. Jurnal Akuntansi Audit \& Aset Universitas Cendrawasih, 1(1), 42-57.

Winardi, R. D. (2013). the Influence of Individual and Situational Factors on Lower-Level Civil Servants' WhistleBlowing Intention in Indonesia. Journal of Indonesian Economy and Business, 28(3), 361-376. 